\title{
HOSTS OF INSECT EGG-PARASITES IN NORTH AND SOUTH AMERICA. II. ${ }^{1}$
}

\author{
By A. Arsine Girault,
}

The University of Illinois, Urbana, Ill.

The additional records of the hosts of insect egg-parasites in North and South America given beyond, comprise those overlooked previously (Girault, 1907) and those recorded in the literature during the years 1907 to 1910 , besides a few as yet unrecorded which are marked with an asterisk in the list to follow. This paper should be considered as a sequel to the first one, and the same arrangements hold here.

Our knowledge in regard to the hosts of hexapod egg-parasites is increasing rapidly, but as far as is yet known, no true insect egg-parasites are other than hymenopterous ${ }^{2}$ and I have but two additional groups to add to those given in 1907 (pp. 28-29), namely the Tetrastichini and Miscogasterini of the Chalcidoidea ${ }^{3}$; the former group may prove to be hyperparasitic on the primary egg-parasites but certainly not ahways. Pentarthron minutum (Riley) still maintains the lead as our most prominent, common and widespread parasite of the eggs of insects, having to date been recorded from thirty or more hosts in North America as well as from several species of the pyralid genus Omiodes (meyricki Swezey, blackburni [Butler], accepta [Butler]) in the Hawaiian Islands, where it was introduced by Albert Koebele about 1900 (Swezey, 1907, pp. 46-47); also in Java it attacks Diatroa striatalis, and in New Zealand, Carpocapsa pomonella Linn. With one or two exceptions, its hosts are all insects of the first economic importance, such as the codling moth, the cotton bollworm, the cotton-leaf caterpillar, the brown-tail moth, the West Indian sugarcane borer and so on. It stills confines itself to the Lepidoptera

1 Part I appeared in Psyche, Vol. XIV, pp. 27-39.

21 am aware of the following sentences of Aaron (1S90): "Finally, we must consider the enemies of the Odonata. In the egg state we have found a small red mite, an Arachnid, which skims rapidly over the water in search of an Odonat egg, upon which it either deposits an egg or excavates it for immediate nourishment. A minute Dipteron, genus unknown, was also seen to oviposit on the egg of Diplax." I know of a true dipterous parasite on Fidia eggs, observed by Mr. Paul R. Jones of the Bureau of Entomology, but unfortunately not reared to maturity. See Johnson and Ilammar, 1910, pp. 55-57, fig. 26. As yet, however, no definite reeords of true dipterous egg-parasites are known to me.

Also perhaps the Pediobiini of the Entedoninæ. 
and Hymenoptera. Phanurus tabanivorus Ashmead is now known to attack Tabanidæ other than Tabanus atratus Fabr., probably some other speeies of the same genus or Chrysops flaridus Wied. (Hine 1907.) The genus Aphanogmus Thomson, recorded from the eggs of Tibicen septendecim (Linn.), is most probably not an egg-parasite but a larval parasite of Ceeidomyidæ ( $c f$. Ashmead, 1893, p. 451; Chittenden, 1909, p. 6) especially sinee Marlatt (1907, p. 129) records predaceous larval Cecidomyids on the eggs of the periodical cieada, and since the subfamily to which the genus belongs is usually parasitic on the larve of Diptera. The records of Aphanogmus floridanus Ashm. from the eggs of the Cicada appear to be based on a supposition.

Of the insect hosts of the egg-parasites, one order, Platyptera, is added to those previously given (Girault, 1907, p. 99), while definite, previously overlooked, records concerning the Odonata are included. Of the hosts known to be parasitized, the parasite unknown, mention may be made of Cecidomyia (?) foliora Russell and Hooker (1908); Notolophus oslari Barnes in Colorado (Hopkins, 1907, p. 143); Malacosoma californica (Pack.) and $M$. constrictor (Stretch) (Isaaes, 1905, p. 102); Craponius incqualis (Say) (Brooks, 1906, p. 240). In passing, I wish to question the record of the eulophid parasites (Pediobius gen. et sp. nov. Tetrastichino) recorded from the eggs of Eriocampoides limacina Retzius by Lawrence (1904); entedonines and tetrastichines are often reared from minute leaf-miners, ceeidomyids and the like and none of the records so far concerning this host are free from suspieion in respect to the presence of these incidental hosts. ${ }^{1}$ Westwoodella Ashmead is parasitic on jassid eggs in the stems of grasses.

Subsequently, the scope of the list will be enlarged to include the world, as it is impossible to ignore the fact that geographical boundaries mean but little in this connection.

Secondary parasitism with egg-parasites was certainly but little known up to several years ago. I had often wondered why this phenomenon did not occur. Several cases are now on record, and even tertiary parasitism, now, is also known to occur.

\footnotetext{
${ }^{1}$ However, in regard to this, compare the record of a Closterocerus from the same host as given below. The Pentarthron was reared at the same time and the former may be secondary, its host the latter species. I think both are primary, however.
} 


\section{Hosts and their Parasites.}

\section{Coleoptera.}

HOST.

PARASITE.

A UTHORITY.

Attelabus analis Illiger Poropxa attelaborum Girault Girault, MS. notes 1910, (U. S. N. M.).

Calligrapha bigsbyana Erixestus wimemana Crawford Crawford, 1910, p. 88. Kirby

Calligrapha scalaris Lec. Erixestus winnemana Crawford Crawford, 1910, p. 88.

Crioceris asparagi Linn. Tetrastichus asparagi Crawford Crawford, 1909 a, p. 150.

Galerucella luteola Müll. Tetrastichus ranthomelane Howard, 1908, p. 281;

Rondani 1

Tyloderma fovcolatum Anaphoidea sordidata Girault fig. 7. Marlatt, 1908, p. 4. Girault, 1909 b, p. 171 . Say

In the Colcoptera, page 29 of the first part of the list, the following changes have become necessary:

Anaphes conotracheli read Anaphoidea conotracheli.

Brachista fidio read Lathromeris fidio.

Tachypterus read Tachyptcrellus.

\section{Hemipter.. \\ HOST.}

Aphis pomi Dr. Geer

Balclutha impicta

Brochymena obscura

Ceresa bubalus Fabr.

Ceresa taurina Fitch

\section{?Anagrus spiritus Girault}

Abbclla subflava Girault

?Trissolcus euschisti Ashm.

${ }^{*}$ Gonatocerus dolichocerus Ashm.

MS.

Ittys ceresarum Ashm.

Polynema striaticorne Girault

Dorycephalus platyrhyn- ?Oligosita americana Ashm. chus Osborn

Enchcnopa binotata Say ${ }^{*}$ Gonatocerus species

Polynema enchenopx Girault P. consobrinus Girault MS.

Euschistus servus Say Telenomus ashmeadi Morrill2 Thyantha custator Fabr. Telenomus ashmeadi Morrill2 Tibicen septendecim Linn.
4 chalcidoids (3 new to the host).
AUTHORITY.

Girault, MS. notes, 1909 , (C. P. Gillette).

Id. (F. M. Webster). Cockerell, 1897, p. 26.

Girault, MS. notes, 1911, (U. S. N. M.).

Girault MS. notes, Illinois, 1908 .

Girault, MS. notes, 1910 , (N. Y. Exp. Sta.).

Girault, $1909^{\mathrm{a}}$.

Girault, MS. notes, 1908, (J. J. Davis).

Girault, MS. notes, 1908, (J. J. Davis).

Morrill, 1907, p. 421.

Morrill, 1907, p. 421.

Marlatt, 1907, pp. 130131.

${ }^{1}$ Introduced artificially from Europe. This may be (Tetracampe) Tetrastichus galleruca (Boyer de Fonscolombe). Rondani did not describe a species called xanthomelana but in 1877 listed and figured Oomyzus galleruca Fonscolombe, but his figures do not agree with those of Howard (1908). However, Marchal (1905) discusses this point and the suggestion is given here without study.

${ }^{2}$ In laboratory. 
In the Hemiptera, pages $30-31$ of the first part of the list, the following changes have become necessary:

Anastatus giraulti Ashmead is a Nomen mudum.

Trichogramma ceresarum read Ittys ceresarum.

Polynema (Cosmocoma) sp. nov.read Polynema striaticorne Girault.

Coccus hesperidum Linnæus-The parasite Trichogramma. flacum Ashmead listed under this host is an unknown Aphelinine, thus doubtless not an egg-parasite; the record should be expunged.

Homalodisca triquetra Fabricius-The parasite Oöctonus homalodisca Ashmead is a nomen nudum.

HYMENOPTERA.

HOST. PARASITE.

AUTHORITY.

Cimbex americana Leach. Pentarthron minutum Riley Severin and Severin, 1908, pp. $68-70$.

Nesomyia eimbicis Brues Brues, 1908, p. 162.

Eriocampoides limacina *Pentarthron mimutum Riley Retzius Girault, MS. notes, 1909, (R. L. Webster). Girault, MS. notes, 1909 , ${ }^{*}$ Clostcroccrus cinctipennis Ashm. (R. L. Webster).

In the Hymenoptera, page 32 of the first part of the list, the following emendations have become necessary:

Trichogramma minutum and T. prctiosum read Pentarthron minutum (Riley) throughout. Anagrus columbi Perk.=Armatus Ashm.

Omit entirely Isosoma spp. and the parasites recorded from them. All of these parasites are doubtless from jassid eggs. See foregoing.

Eriocampoides limacina Retzius.-The parasite "Encyrtus" species is doubtless Pentarthron minutum (Riley), referred to thus by Peck (1799).

\section{LePidopter.}

HOST.

PARASITE

AUTHORITY .

Agraulis vanille Linn. *Pentarthron minutum Riley

Anisota senatoria Smith *Pentarthron minutum Riley and Abbot

(Archips) Cacccia rosa- *Pentarthron minutum Riley ceana Harris ${ }^{1}$

Carpocapsa pomonella Anaphes gracilis How.

Linnæus

Girault, MS. notes, 1910, (Bur. Ent.).

Girault, MS. notes, 1910. (Bur. Ent.).

Girault, MS. notes, 1908.

Girault, MS. notes, 1911. (U.S. N. MI.). 
HOST.

PARASITE.

AUTHORITY.

Datana integerrima Grote ${ }^{*}$ Pentarthron minutum Riley and Robinson

Diatrca saccharalis $\quad$ Pcntarthron minutum Riley Fabricius

Chalcidoid

Euproctis chrysorrhaca Telenomus phalcnarum Nees? Linn.

Pentarthron minutum Riley

"Pentarthron euproctidis Girault" Girault, MS. notes, 1910. (Bur. Ent.).

Hemerocampa leucostigma Tclenomus dalmani Ratz Brues, 1910, p. 107. Smith and Abbot.

Heterocampa guttivitta Telenomus grapta Howard Walker

Hyphantria textor Har- ${ }^{*}$ Pentarthron minutum Riley ris

Malacosoma disstria Oöencyrtus clisiocampa Ashm.

Hübn.

Meliana albilinca Hübn. Pentarthron rctorridum Girault

Fiske and Burgess, 1910, p. 390 .

Girault, MS. notes, 1910, (Bur. Ent.).

Ashmead, 1900.2

Girault, MS. notes, 1910, (R. L. Webster).

Notolophus oslari Barnes Telenomus coloradensis Crawford

Crawford, 1909 , pp. 206207.

Porthetria dispár Linn. Schedius kuvana Howard";? Howard, 1910, pp. 3-4.

Tyndarichus navo Howard. Antatus bifasciatus FonId. Ib. pp. 6-7.7; 8 Id. Ib., pp. $7-8 .{ }^{2} ; 7$ scolombe日

Perissopterus jarensis Howard Telenomus new species

Id. Ib., pp. 11-12.'

Id. Ib., p. 12.2 Ashmead, 1898, p. 24.

Smerinthus astylus Drury Anastatus pearsalli Ashm.

Corrections to Lepidoptera pages 32-35.

Trichogramma pretiosum, T. intermedium, T. minutum, T. minutissimum should read throughout Pentarthron minutum (Riley).

Calpodes ethilius Cramer-The "Trichogramma" species is Pentarthron minutum (Riley).

Hemerocampa lencostigma $\mathrm{Sm}$. and Ab.-The parasites Trichogramma fraternum Fitch and $T$. orgyice Fitch are eulophids and not egg-parasites.

Neuroptera.

HOST.

PARASITE.

Chauliodes rastricornis Pentarthron minutum Riley Rambur.
AUTHORITY.

Needham and Betten, 1901, p. 547. 


\begin{tabular}{|c|c|c|}
\hline \multicolumn{3}{|c|}{ Odonata. } \\
\hline Host. & PARASITE. & AUTHORITY. \\
\hline $\begin{array}{l}\text { Lestes uncala Kirby } \\
\text { L. unguiculata Hagen }\end{array}$ & $\begin{array}{l}\text { Brachistclla aeuminata Ashm. } \\
\text { Centrobia odonate Ashm. } \\
\text { Polynema necdhami Ashm. } \\
\text { Iypertcles polynema Ashm. }{ }^{4} \\
\text { Tetrastichus polynemo Ashm.5 }\end{array}$ & $\begin{array}{l}\text { Ashmead, 1900b. } \\
\text { Needham, } 1900 . \\
\text { Needham, 1903, p. } 230 .\end{array}$ \\
\hline
\end{tabular}

\section{Orthoptera.}

Anazipha exigua Say

Mantis sp.

Oecanthus niveus Deg.

Geer

Stagmomantis carolina Linn.

\section{Cacilius aurantiacus}

Hagen

\author{
Polynema bifasciatipenne \\ Girault \\ Eupclmus brevicauda Gahan \\ Polynema bifasciatipennc \\ Girault \\ Eupelmus mantis Ashm. \\ Girault, 1908s. \\ Gahan, 1910, p. 205. \\ Girault, 1910, p. 255. \\ Ashmead, 1885, p. xv.
}

\section{Platyptera.}

Alaptus crcilii Giraulto

Girault, 1908s, pp. 180, $181,191$.

\section{Literature Refcrred to.}

1877. Rondani, C. Vesparia parasita non vel minus cognita. Bull. Soc. Ent. Italiana, IX, pp. 190-191, tav. II, figs. 64-67.

1885. Ashmead, W. H. Trans. Amer. Ent. Soc., XII.

1890. Aaron, Mrs. C. B. Life histories and structures of the Odonata. In the

Dipterous enemies of man: Their life histories and structure. A treatise on their extermination. Dragon Flies versus Mosquitoes. The Lamborn prize essays, New York, II, p. 50.

1893. Ashmead, W. H. Monograph of the North American Proctotrypidæ. Bull. U. S. Nat. Mus., No. 45.

1897. Cockerell, T. D. A. Canad. Ent., XXIX, p. 26.

Enock, Fred. Proc. Ent. Soc., London, p. xvirI.

1898. Ashmead, IV. H. Ent. News, IX.

1900. (a) Idcm. Proc. U. S. Nat. Mus., XXII, p. 382.

\footnotetext{
1Reared by MIr. J. J. Davis, Chicago, Ill. ${ }^{2}$ Introduced artificially from Europe. ${ }^{3}$ The rearing as recorded by Needham does not distinguish between the hosts, so it is taken for granted that the parasites are eommon to both. Ashmead merely gives Lestes species. Needham records at first five egg-parasites and one hyperparasite, whereas Ashmead records five from the egg of Lestes sp., but states Hyperteles polynemce and Tetrastichus polyneme, as their names indicate, to be parasitic on Polynema needhami, novel cases of secondary parasitism. Later, Needham ehanged the record to agree with that of Ashmead. "4"Evidently a hyperparasite on the Polynema noted below." Ashmead, 1900, p. 616. "5ndoubtedly a hyperparasite of Polynema needhami." Ashmead, 1900, p. 616. "In England Enock (1597) records Alaptus fusculus Walker and a supposed male specimen of A. minimus Walker from the eggs of Stenopsocus cruciatus (Linnæus), a record overlooked in Girault, 1905\%. aThis is the first record of egg-parasites in the Platyptera. (See Giranlt, 1910, p. 244.) Fimported into Massachusetts from Japan. SSecondary on Schedius; cf. Howard. 9Pachyneuron gifucnsis Ashmead should be mentioned here as a secondary parasite of the Schedius and Anastatus and as tertiary upon the Tyndarichus. (Howard, 1. c., p. s). And also see Atoposomoidea ogima Howard on the pages following (1. c). ${ }^{10} \mathrm{I}$ have verified this record through specimens reared from the same host in North Carolina. 11This is the Trichogramma sp. of Fiske (1910).
} 
(b) Idem. Some hymenopterous parasites from dragon-fly eggs. Ent. News, XI, pp. 615-617.

Needham, J. G. Amer. Naturalist, XXXIV, p. 375, footnote.

1901. Needham, J. G. and C. Betten. Bull. N. Y. State Mus., No. 47.

1903. Needham, J. G. Bull. N. Y. State Mus., No. 68. (Aquatic insects in New York State-Necdham, MacGillivray, Johanssen and Davis.)

1904. Lawrence, W. H. Bull. Washington State Agric. College, Pullman, No. 65, p. 13.

1905. Isaac, John. Bug vs. bug. First biennial Rep. Commissioner Horticulture State of Calif. f. 1903-1904, Sacramento.

Marchal, Paul. Bull. Soc. Ent. France, Paris, pp. 81-83, fig. Extract.

1906. Brooks, Fred E. Bull. No. 100, W. Va. Univ. Agric. Exp. Sta.

1907. Girault, A. A. Hosts of insect egg-parasites in North and South America. Psyche, XIV, pp. 27-39.

Hine, J. S. Bull. Louisiana Exp. Sta. No. 93, pp. 11-12, fig. 4.

Hopkins, A. D. Proc. Ent. Soc., Washington, VIII.

Kirkland, A. II. Second annual report superintendent for suppressing the Gypsy and Brown-tail Moths. (Commonwealth of Mass. Public Document, No. 73.)

Marlatt, C. L. The periodical cicada. Bull. Bur. Ent., No. 71, U.S. Dept. Agric.

Morrill, A. W, Amer, Naturalist, XLI.

Pierce, W. D. Ent. News, XVIII.

Swezey, Otto H. The sugar cane leaf-roller (Omiodes accepta) with an account of allied species and natural enemies. Rept. Exp. Sta., Hawaiian Sugar Planters' Assoc. Bull., No. 5, Div. Ent.

1908. (a) Girault, A. A. Descriptions of three new North American Chalcidoidea, etc. Psyche, XV, p. 117.

(b) Idem. A monographic catalogue of the Mymarid genus Álaptus Haliday, etc. Annals Ent. Soc. Amer., I, pp. 180, 181, 191.

Brues, C. T. Bull. Wisconsin Nat. Hist. Soc., VI, October.

Howard, L. O. The importation of Tetrastichus xanthomelante (Rond.) Journal Econ. Ent. I, pp. 281-289, fig. 7.

Koelsele, A. Insect investigations in Mexico. Rep. Div. Ent., 1907. 4th Rep. Board Commissioners Agric. and Forestry, Territory of IIawaii, Honolulu.

Marlatt, C. L. Circular Bur. Ent., No. 8, U. S. Dept. Agric., revised edit., p. 4. Russell, H. M., and C. W. Hooker. Ent. News, Philadelphia, XIX, p. 352. Severin, H. H. P. and H. C. M. Severin. Habits of the American Saw-fly, Cimbex americana Leach, with observations on its egg-parasite, Trichogramma pretiosa Riley. Trans. Wis. Acad. Sci. Arts and Letters, XVI, pt. I.

1909. Chittenden, F. H. Cir. Bureau Ent. No. 104, U. S. Dept. Agric.

(a) Crawford, J. C. Proc. Ent. Soc. Washington, XI.

(b) Idem. Ibid.

(a) Girault, A. A. Psyche, XVI, pp. 106-107.

(b) Idem. Jour. N. Y. Ent. Soc., XVII, December. 
1910. Crawford, J. C. Proc. U. S. Nat. Mus., 38, May 3.

Brues, C. T. Psyche, XVII, June.

Fiske, W. F. Parasites of the Gypsy and Brown-tail Moths introduced into Massachusetts. Boston (State Forester's Office), p. 55, table V.

Fiske, W. F. and A. F. Burgess. Jour. Econ. Ent., III, October.

Gahan, A. B. Canadian Eut.

Girault, A. A. Journ. N. Y. Ent. Soc., XVIII, December.

Howard, L. O. Bull. Bur. Ent. Tech. Ser., No. 19, U. S. Dept. Agric., January.

Johnson, F. and A. G. Hammar. Bull. Bur. Ent., No. 89, U. S. Dept. Agric.

\section{TWO NEW NAMES OF SPHECOID WASPS.}

\section{By S. A. Rolwer,}

U. S. National Museum, Washington, D. C.

The following two names purposed by Billberg in 1820 have generally been overlooked by Hymenopterists.

\section{Genus Ammobia Billberg.}

Ammobia Billberg, Enumartio Insectorum, 1820, p. 105.

Type--Pepsis argcntata Fabricius.

Chlorion (Ammobia) umbrosum (Christ.).

Syn.-Proterosphex H. Fernald. Ent. News, vol. 16, 1905, p. 165.

This genus was originally treated as follows (Eg. equals Billberg):

"G. Ammobia Eg.-Amophila Krb. Latr. Ed. cuc.-Pepsis Fbr.Spnl.-Miscus Jur.-Sphex Auct. coet.

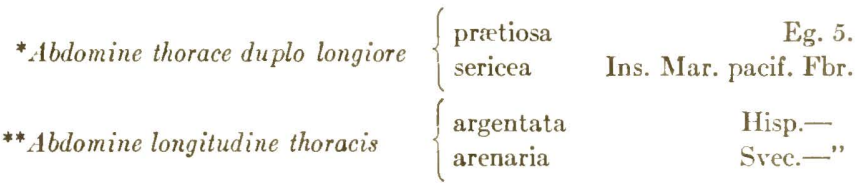

The first species included, protiosa Billberg, is a nomen nudum. The second species, Pepsis sericea Fabricius, is a variety of Sphex (F. F. Kohl) aurulentus oceurring in the West Indies so probably was not before Billberg and should not be taken as the type.

The third species, Pepsis argentata Fabricius, is a common European species; is a synonym of Sphex (F. F. Kohl) umbrous, and may be chosen as the type of Ammobia. 

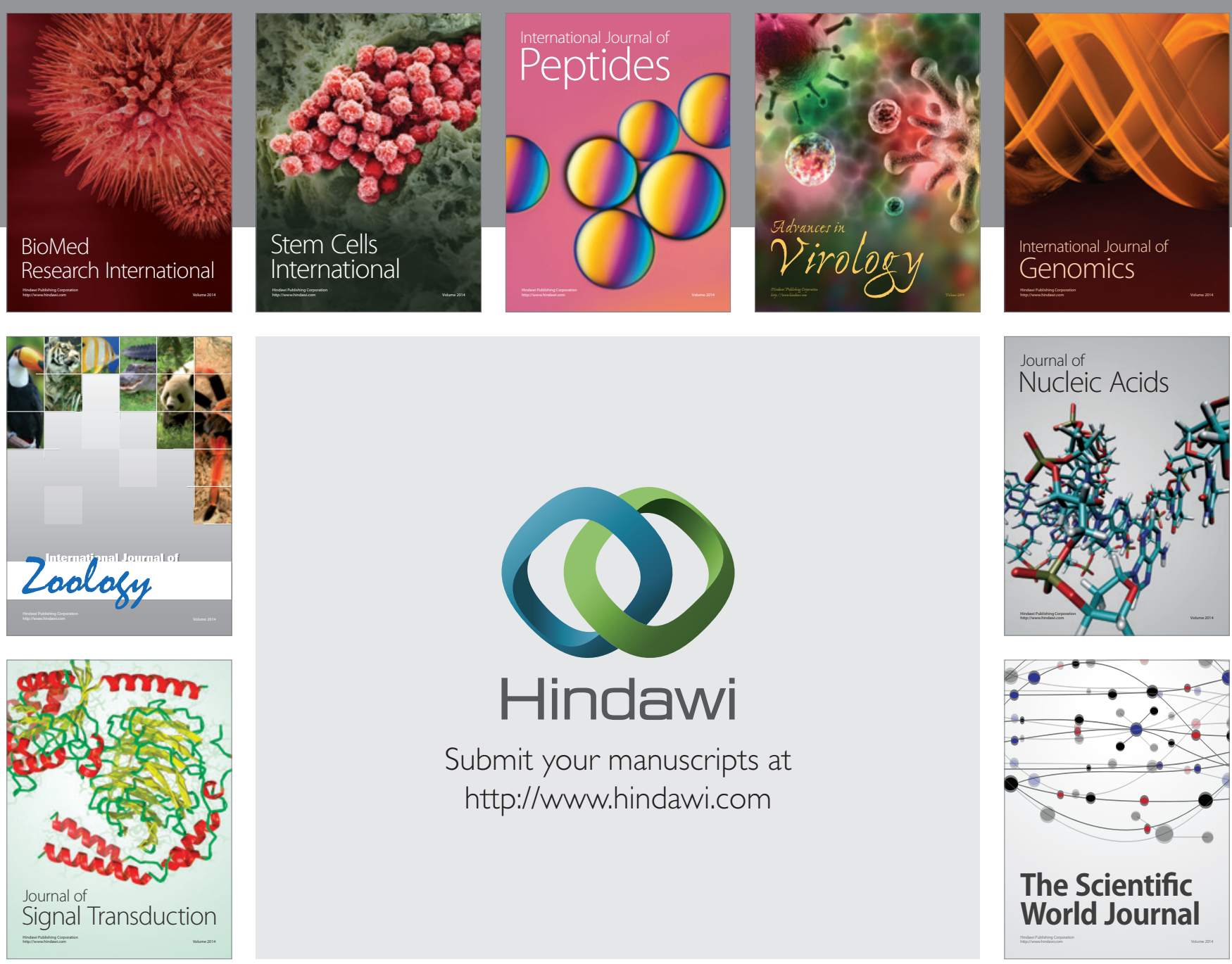

Submit your manuscripts at

http://www.hindawi.com
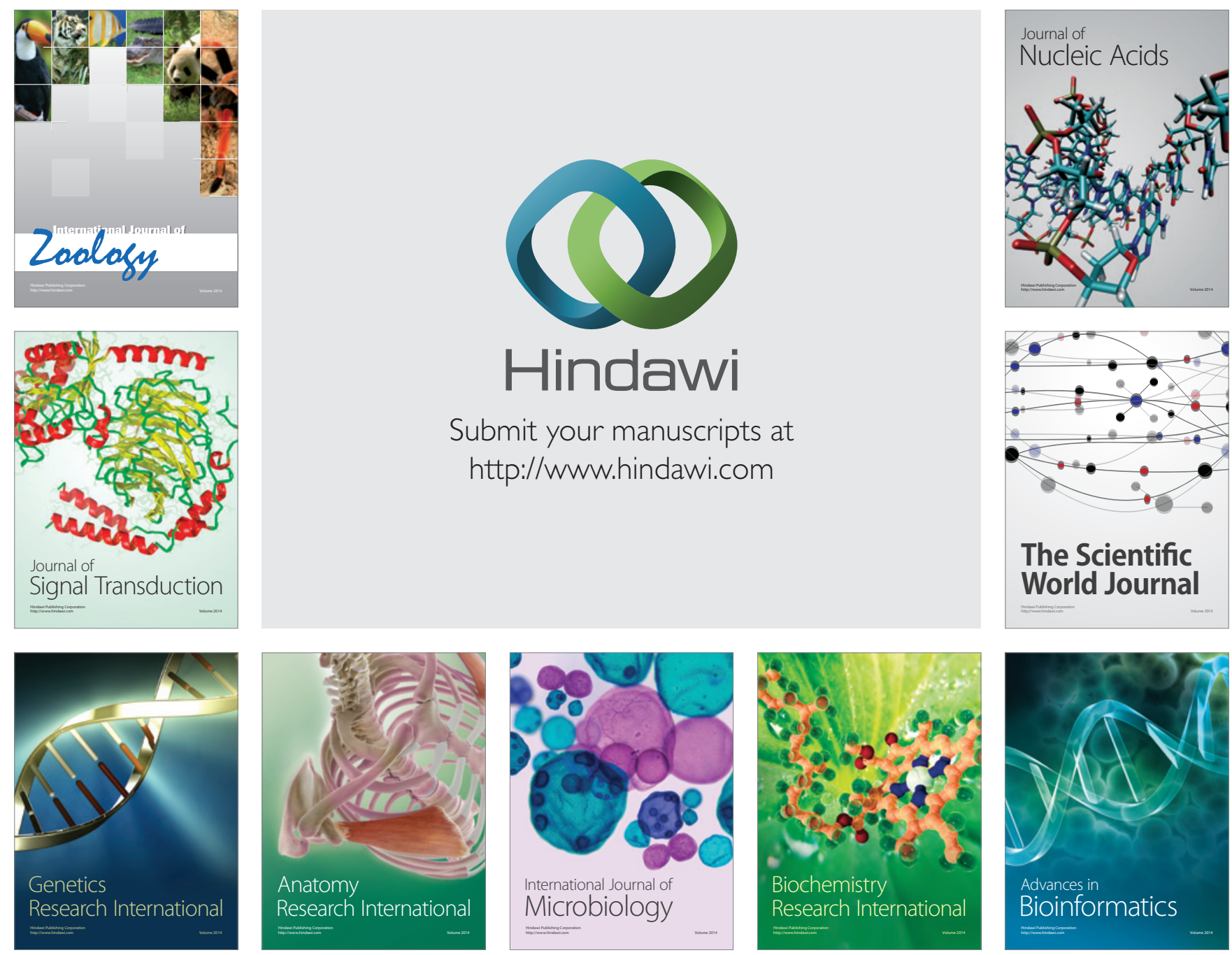

The Scientific World Journal
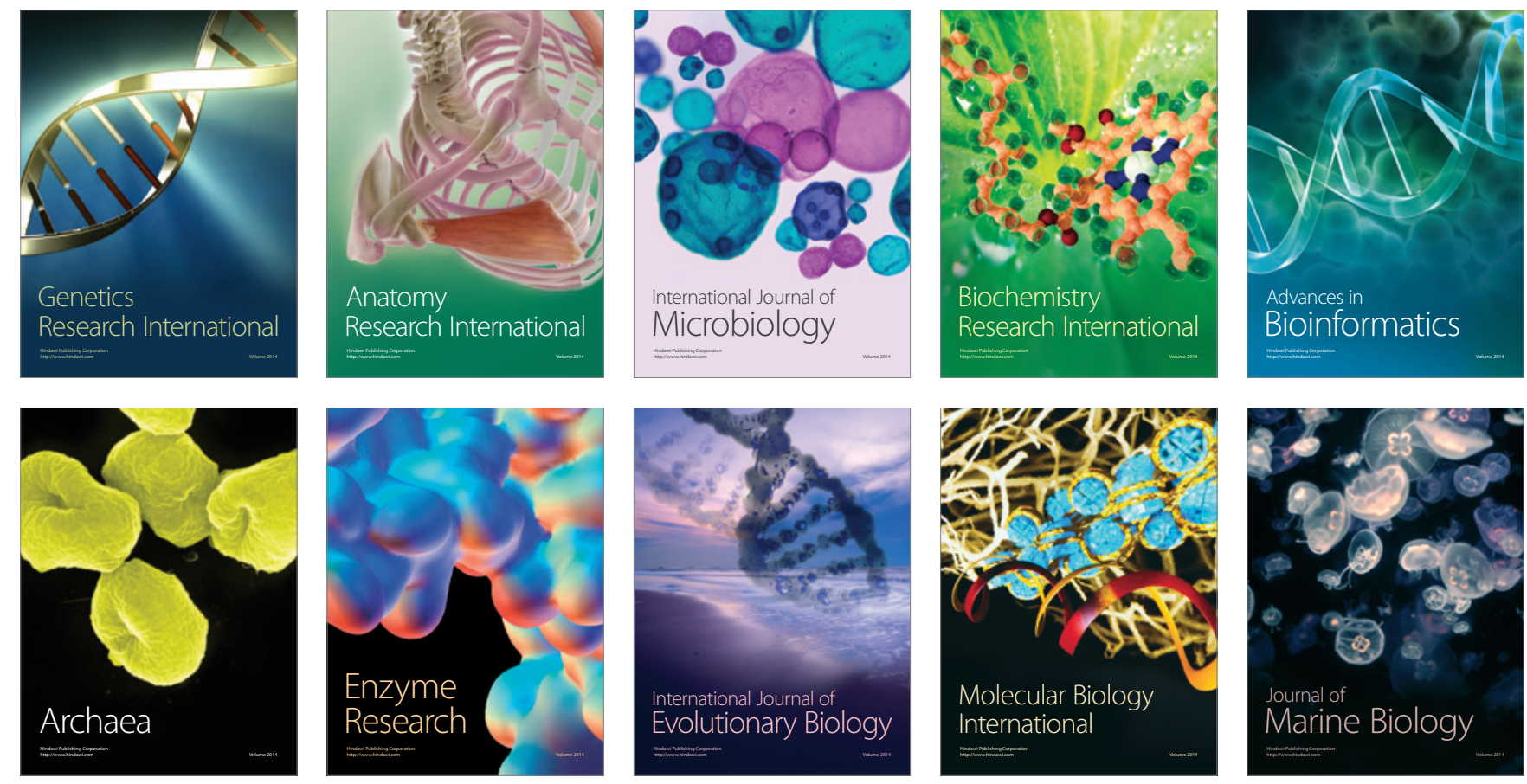